\title{
Psychological Analysis on Autogenesis as Preface to God Cognition (A Comparative Analysis of View Point of Imam Ali ibn Abu Talib --peace be upon him-and Scholars of Education and Pedagogy)
}

\author{
Seyed Eshaq Hoseini Kuhsari ${ }^{*}$ \\ Ali Redha Mohammad Redhaei ${ }^{1}$ \\ ${ }^{1}$ Tehran University \\ Email: amredhaei@ut.ac.ir
}

\begin{abstract}
One of the questions which has engaged the mind and soul of many people is: how can fifteen century old teachings of Islam and its guide lines given by Prophet Mohammad (peace be upon him) and infallible Imams (peace be upon them) can answer the needs of today and how can it lead the way of today's people to perfection? Is the teaching of Islam compatible with science of today?

The present papertries to emphasize on teachings of Islam not belonging to people of specific time period, and have static and variable laws and comprehensive view on every aspect of life. It also performs an analytic and comparative study on viewpoint of psychologists and sayings of Imam Ali's concerning the most fundamental need of humanity; Autogenesis and perfectionism. Probably it may help us answer the above questions and will also help us in manifesting some part of that infallible Imam's endless knowledge.
\end{abstract}

Keywords: Autogenesis, God Cognistion, Imam Ali (peace be upon him), Education and Pedagogy.

\section{A. INTRODUCTION}

When the crier of the truth with his beautiful voice, settled the echo of love, zeal and hope in his enlightened heart and hummed the call "Read in the Name of your Lord who created" on the mountain of light, and sent it as a gift with the caller of mercy towards the humanity, and the very first person who drank from the Prophetic spring and quenched his life taking thirst and plunged into its life saving waves of wisdom, was none other than the cousin of Prophet, a highborn person from the progeny of BaniHashim, the very person who grew up in the arms of Prophet (pbuh) and whose words and speech, and actions and behaviors were like Prophet himself, because he was the essence and the soul of Prophet.

Finishing the chain of sending the Prophets and completing the religion of Islam can be proved by the following verses "Indeed, with Allah religion is Islam" and "Today I have perfected your religion for you, and I have completed My blessing upon you, and I have approved Islam as your religion" and "Muhammad is not the father of any man among you, but he is the Apostle of Allah and the Seal of the Prophets". So now it (Islam) should be able to answer the questions of people in every aspect of their life and in every time period. In a tradition it has been mentioned: "Indeed, God has not sent it for a specific time period or for a group of people, hence it will remain new and fruitful for every nation till the day of resurrection" regarding the element of synchronization between the laws and rules of Islam and the changes occurring day by day Dr. Walger writes: "we are becoming more and more surprised by the religion whose fundamental principles of ethics is 
based on discipline and incumbency, and moulds its laws so accurately concerning the duty of a person regarding himself and others that it accepts all kinds of transitions and evolution, and which is compatible with all types of intellectual advancement". About Holy Qur'an being comprehensive and taking all aspect of human's life into account and not leaving any area in which man needs divine guidance, Edward Gibbon writes: "Qur'an... contains a collection of religious, social, civil, business, military, judicial, criminal and punitive laws. From day to day problems of life to religious rituals, from self purification to physical health and hygiene, from public rights to personal rights and to social benefits, and from ethical values to crimes, and from punishment of sins to complications of the future, all these are mentioned in the collection of those laws" (Shakirin, Hameed Reza, 2006). Teachings of holy Prophet and precious sayings of Imam Ali (pbuh) and other infallible Imams are not just clarification and interpretation but also a clear exegesis of the entire Holy Qur'an. These teachings are the precious treasure that has scrutinized the Qur'anic facts and has presented it in the best form to the humanity and it has been and will be the light to show the humanity the path of prosperity. Holy Prophet (pbuh) did not say it without any reason that "I am the city of Knowledge and Ali is its gateway". It is clear that Islamic manifesto The Holy Qur'an is firmly rooted into his soul and he provided them to generations in different occasions to find them at the way of absolute perfection, with the mode of pure divine nature and so that they could distinguish pure from impure.

His precious sayings, advices and wisdoms are the bright lamp of guidance and the life boat for the salvation of humanity. One of bright pearls is his brief words in which Imam Ali indicated about the sequence and order of God- -cognition on auto gnosis and has mentioned the evident effect which sometimes intentionally and sometimes unintentionally occurs regarding self-awareness. Auto gnosis is one of the basic needs which has grasped the attention of psychologists from the beginning of twentieth century and has become a fundamental principle of personality and behaviour analysis. This article tries to throw some light at the viewpoint of some psychologists such as Sigmund Freud and Kari Hurray on the basis of this saying:"Someone who knows himself knows his God". It is very likely that the spring of divine wisdom, Imam Ali (pbuh), could point out toward the answers of some unanswered questions regarding human nature.

\section{B. METHODOLOGY}

Paper present to emphasize on teachings of Islam not belonging to people of specific time period, and have static and variable laws and comprehensive view on every aspect of life. It also performs an analytic and comparative study on viewpoint of psychologists and sayings of Imam Ali's concerning the most fundamental need of humanity; Autogenesis and perfectionism. Probably it may help us answer the above questions and will also help us in manifesting some part of that infallible Imam's endless knowledge.

\section{RESULT AND DISCUSSION}

\section{Psychology of Personality}

The terminology of Personality in psychology has grasped the attention of the behaviourists, more than any other context. The importance of understanding this concept is so much that failure to understand it precisely can lead to the disturbance in psychological research studies. (Alan 0 . Ross, 1992) 
The theory of Greek philosopher Theophrastus (371-281 BC) is among the oldest theory of behaviour and character - based personalities, he believed that each of us could recognize the other character by using our reasoning and experience.

Gordon Allport, according to most of the scholars is the founder of new studies regarding personality, and views it as a set of internal factors which leads to all the individual activities. (Saeed Shamlu, 2003).

According to the above-mentioned definitions, we can conclude that the psychology of personality as a combination of actions, thoughts, excitements and personal stimuli, which appears while a person, interacts with us and others.

Attention of holy Qur'an and traditions of infallible Imams towards man's existential dimensions is not hidden from anyone. As Imam Ali says: "the best cognition is auto gnosis (self-awareness)"; is referring towards the words of the Creator who says: "certainly insights have come to you from your Lord. So whoever sees, it is to the benefit of his own soul, and whoever remains blind, it is to its detriment, and I am not a keeper over you." (Ch: An'aam: V: 104)

Hence, the purpose and the ultimate goal of the Prophets and Apostles of God has been influencing the heart and souls of mankind, because the influence constituted on the self and soul by the slightest action of a man during his life effects man's character, behaviour and personality. (Ali Reza A'arafi, 1997).

\section{Autognosis (Self - Awareness)}

The skill of self-awareness or "autognosis" is one of the fundamental skills. Autognosis can be defined as man's ability towards understanding individual and social qualities in such a way that he is able to acquire true cognition of his strengths and weaknesses, interests and tendencies, needs and requirements and different aspects of his existence. And in the light of which, one achieves social and individual compatibility. Such cognition can be named as "insight". From Qur'anic point of view man has insight of his soul: "Indeed, man is a witness to himself". (Ch: Al - Qiyamat; V: 14)

In context to the importance of self-awareness and insight to oneself, it is enough that not having religious awareness and knowledge is way too easier than not having insight and self-awareness. In comparison to all other cognitions, Self-cognition has the highest rank.

When in verses of Qur'an, in traditions and in brief precious sayings of Imam Ali's, autognosis is discussed as the way of reaching the God cognition, probably the reason behind it is that in the process of evolution and scientific advancement of mankind and discovery of new dimensions of man's personality, for example, can have a vital role in leading the man towards perfection, and can explain some of the meanings of "self" which are hidden beyond the word of "Oneself", and which is divided into two parts "Real self" and "Ideal self".

Karen Horney encourages man towards "Ideal self" in her book "Theories of Personality".

She believes that awareness from the real self, potential talents and the abilities one has, makes the man unable to be succumbing to the environment of the society and can sometime take the initiative and distinguish his personality and make it better from other people who are influenced by the same social and cultural factors. 
Horney believes autogenesis and converting potential natural ability into reality, as an ethical duty and man's spiritual advancement and considers it as the result of ethical evolution.

Sometimes man is not satisfied just with the cognition of Real-Self and flourishing his potential natural abilities, but moves towards the cognition of Ideal-Self; wishing to reach the perfection. (Same)

In the book Peak of Eloquence (Nahjul Balagha), in the saying 149, Imam Ali (pbuh) says: One who does not realize his own value is condemned to utter failure.

The point indicated here is that lack of awareness and ignorance from oneself, can lead to destruction and doom. And one cannot attain cognition of himself unless he understands the philosophy of his creation.

One of the famous contemporary psychologist, Sigmund Freud, believes: "our knowledge of that we exist and where we exist, what are our needs and interests and have emotions and what is happening around us; all these together creates consciousness and apparent intelligence... however, since man cannot understand himself completely, so his personality is constituted only by the partial knowledge he has about himself and the major part of his personality is built up with his inner consciousness or unconsciousness. (Ali Akbar Seyasi, 1991).

He has compared the psyche of a man to an iceberg which is floating in sea and its major part is under the water, which is the centre of instincts, desires and wishes and has great impact on man's behaviour. (The same reference, page 14-15)

Also according to Abraham Maslow, a perfect man wants to bloom his personality by correct and constructive ways. (Hess Fist, 2005).

On the other hand, Freud has also divided man's personality into three components; Id, ego and super-ego. (Aryanpour, 1978) Freud views Id as a main component of the system of personality, in which, all the things which a person experienced since the time of his birth constitutes the experience of his inner world. The id is an unorganized part of the personality structure that contains a human's basic and instinctual drive. The ego acts according to the realityprinciple and seeks to please the drive in realistic ways. The superego reflects the internalization of moral and ethical values, mainly taught by parents applying their guidance and influence. (Rickey L. George, 2002).

Exactly what the holy Prophet said: "Each child is born on a natural instinct, it is the parents who make them (children) Jewish or Christian, or Zorastrian". (Behar Al-Anwar, Volume 2).

Man's behaviourism or individual behaviours returns back to the tradition and valuable remarks of Imam Ali (pbuh) "I am surprised by someone who doesn't know himself but claims to know his God?!" (Mohammad Dashty, 2007).

Centuries before the theories of psychologists, Imam Ali (pbuh) said: "May God have his mercy on someone who knows from where he has come, where he is and where will he go" (Mohammad Ja'far Pakserisht, 2007).

Freud also considered the three mentioned possibilities in context of autognosis. He said that a man should know: 
1. From where did he come and where was his beginning point?

2. Where he is and what is his current situation?

3. And in the end where he will go?

In this regard, Maulana Jalal-Uddin Balkhi has composed a beautiful couplet:

All day I think about it, and then at night I talk about it.

Where did I come from, and what am I supposed to be doing? I have no idea.

My soul is from elsewhere, I'm sure of that,

And I intend to end up there (Mustafa Rahimi Niya, 2006).

Therefore, a person who doesn't know the dos and don'ts suffers the distance from humanitarian principles and moral standards. A contemporary psychologist, Albert Bandura, believes that distancing from these principles and standards causes self-contempt, and self-contempt leads to the feeling of disability.

Bandura says: expected expostulation which one will receive by himself for crossing the moral standards, creates a motivational source, which helps him abide the moral standards in the presence of other stimulatory factors, and there is no worse punishment than self-contempt. (Ali Akbar Saif, 2005) and self-contempt can be seen in the actions of a person in different ways:

Imam Ali (pbuh) says: If a person goes to meet a wealthy person and shows him his modesty because of his wealth, he has sold two third of his religion.

According to this wisdom, wealth of a wealthy man is not a privilege, for lack of which a poor man suffers with inferiority complex in front of a rich man.

And if a person goes through that feeling then that is the sign of lack of moral standards. In holy Qur'an Allah almighty says: "Rather, your possessions, and children are a test" (ch: Taghabun, verse: 15)

Therefore, ignorance of a man towards his possession becomes a reason for the accession of inferiority complex and becomes eminent in his actions.

Alfred Adler believes that most of the unusual and strange behaviours of a society have its roots in inferiority complex. (Parirukh Dadsetan, journal of Psychology, first year, edition 40)

He says: "inferiority complex is a result of not being able to attain your needs and being surrounded by stronger and more capable adults, and at last being forced to be dependent on the conditions of the environment. Feeling incapable means feeling weak."

Perhaps a man, to compensate his deficiencies bows down in respect to a rich man of a society, or tries to pretend to be despicable and abhorrent in front of the wealthy man.

Similarly holy Prophet said: "there are a lot of people who try making themselves favourites but indeed make themselves despised." (Amody, 2000).

Imam Ali in the letter number 31 of Nahjul Balagha to his son Imam Hasan says: "Keep your soul great and superior by avoiding any meanness." 
However, being humble and submissive to others is not always the sign of weakness and incapability; rather it is a sign of generosity and intelligence, and in such conditions, these kinds of behaviours are perfectionist and full of optimization, and it is a process of perfectionism and achieving fulfilment.

Maulana has also not ignored this kind and said:

A drop of rain dropped from the clouds

It felt ashamed when saw the width of the sea

I am nothing in comparison to the sea

Indeed only the sea is there and I am nothing

And when it saw itself with the eyes of inferiority

Pearl fostered it inside itself

It gained the height higher than the mountains

It remained in inexistence until it existed. (Rahimi Niya, 2006).

So, if man instead of feeling discomfort, unhappiness and humiliation, takes the advantage of his great inner power and get to his wishes in that way he can compensate his lacks.

The Imam of the Shia world says: "O man, you think that you are weak and incapable, while the universe with all its complexity has been created for you, which means your power and energy, is unlimited". (Majid Rashidpour, 1984) .

Adler considers inferiority complex as best motivation for man towards the perfection.

This is while, self-contempt and self humiliation may cause moral and ethical deviation in society.

Defamation and back biting others are the results of moral deviations. Imam Ali (pbuh) considers it as a result of man's inability and says: "Backbiting is the attempt of an incapable man."

Imam Ali points out towards the backbiters in brief and precious words, as an act of a helpless man, who has found himself helpless in front of reasoning and logic, or he hasn't attained what he wanted and in that case, he got indulged in the act of backbiting, and since he didn't succeed, so he blames others for his failure.

Sigmund Freud regarding a person being helpless in doing his duties believes that being hopeless for attaining a goal, finding excuses for his inappropriate behaviour and blaming others for it, are among the most famous examples of Defence Mechanism, Sublimation and Psychological Projection. (John, 2004).

Contemporary psychologists of personality believe reprehension of a person for his failure is less dangerous than the reprehension of the person himself. (Duane Schultz, 2008).

So, a backbiter has a feeling of inferiority complex regarding that person, since he cannot see the success and advancement of that person, he starts gossiping about him.

One, whose harvest has burnt, doesn't want someone else's candle blazing.

In his well-known theory, Martin Seligman says about personal backbiting: when we face a failure, by blaming it to some reasons, we justify our problems and lack of control over ourselves. He 
believes that a pessimist faces failures because of his inner reasons and an optimist, because of his outer reasons. For instance: if you fail in an exam and attribute it to inner reasons, you will tell yourself that there is a problem in you perhaps, you are not bright enough to pass this exam. But if you attribute it to outer reasons, then you will think that the flaw is somewhere else, perhaps your teacher doesn't like you or your job doesn't leave you enough time for studying. (Same reference, page 499)

In a precious narration quoted from Imam Ali (pbuh), he says: "O' people, blessed is the man whose own flaws keep him away from (looking into) the flaws of others" (Mohammad Dashti, 2006).

Hence, a person who does backbiting is either because of inability or weakness, and because of that, he can't take back his rights, and thinks that the only way to get back his right is through backbiting and gossiping, which eventually increases his weaknesses.

Lack of self-regard and self-respect makes a person feel frustrated and that feeling leads towards aggressiveness.

Stress, anger and aggression, cognitive impairment and depression are a few prevalent psychological reactions to mental stress and tension. Wisdom 746 of Nahjul Balagha confirms the mentioned facts in which Imam Ali (pbuh) says: "madness is the beginning of anger and regret is the end."

Anger is a psychological condition which causes blood circulation in the body of a man. An angry man loses his contemplation intellectualization, and turns into a wild animal; and so he indulges into unreasonable acts.

Anger is not something which just happens unexpectedly and out of compulsion but it is a state in which man is completely aware, conscious and in control.

According to the famous contemporary psychologist, Albert Ellis, the root of all problems and turmoil lies in irrational thoughts. He says, "It is not the things which disturb a man, but it's the irrational ideology and his view point towards those things that disturbs him. (David D. Burns, 2001).

Anger and rage annihilates intellect and wisdom, and someone who gets angry, surely lacks patience and tolerance, and cannot take wise and intellectual step, and ties himself up with the chains of anger, hatred and enmity.

It is quoted in the book of Ghurar Al-Hikam and Durar Al-Kalim from Imam Ali (pbuh): "Anger corrupts the mind and carries away from the right path."

Yusuf Karimi, in his book "Social Psychology" expresses his idea regarding the outcomes of anger and rage as: "this instinct, if possible, tries to destroy and annihilate others and if it fails to target others, the aggression returns to the person himself, which ends up in self-destruction and suicide. (Karimi, 1994).

Holy Prophet (pbuh) said: "الغضب يفسد الأيمان كما يفسد الخلّ العسل". Anger destroys faith as vinegar destroys honey. (Sheikh Koleini, 2002, Vol: 3, page 412) 
However, there are some high self-esteem people who easily face their life's tension and their spiritual calmness is not affected easily. (Mohammad Naqi Barahini, 2006).

Kobasa, calls such people "men of resistance". Member of group (B) in contrary to member of group (A) can work without getting confused; they don't have hasty and compulsive nature, thus they have a lot of patience and don't get angry easily. (Rita L. Atkinson and..., 2005)

Saying of Imam Sadiq ( ) is enough to condemn the anger: "الغضب مفتاح كل شر". Wrath is the key of all wickedness. (Koleini)

Among other reactions of a desperate and helpless man is the appearance of jealousy drive. A helpless person, who is breeding hatred and enmity in himself, hopes that the person he hates gets into trouble, and sometimes he persuades the other person to hurt him. Like Cain son of Adam, kills his brother Abel, or like Josef's brother pushed him into the well. "And (say, I seek protection of the Lord) from the evil of the envious one when he envies" (Ch: Falaq, verse: 5)

Narrations and traditions have introduced an envier as unhealthy and sick person. Like in Nahjul Balagha wisdom 256 Imam Ali (pbuh) says: "صحّة الجسد من قلّة الحسد". Health of a body lies in avoiding jealousy.

As per the saying of Imam Ali (pbuh), many contemporary psychologists believe, jealousy is the main source of many sicknesses. Thus, it has been proved by science that sickness such as ulcer and many other internal sicknesses occur from mental disturbance and anxiety, and jealousy forms the very basis of all of them. (Mohsen Abbas Nejad, 2005).

A word of Imam Ali (AS), in Nahjul Balagha wisdom 225 consolidates the words of psychologists, he says: "العجب لغفلة الحُسّاد، عن سلامة الأجساد". I am surprised by the jealous person's ignorance towards his health.

According to the views of Imam Ali (pbuh) and psychologists of personality, we can say: "a jealous person is usually sensitive, sick, depressed and aggressive and different parts of his body come under the attack of his mental states. Sometimes even the friends of an envier leave him alone.

As Imam Ali (AS) says: "لا راحة مع حسد". There is no peace with jealousy.

Rushd Uddin Vatvaat has beautifully composed the words of Imam Ali (pbuh) in couplets:

1. Avoid jealousy and live happily

2. With jealousy nobody can be happy

3. If you want to marry joy

4. You must divorce jealousy (Rushd Uddin Vatvaat, 1986, page 19)

Since a jealous person, always is in torment from the success and advancement of others, and the inferiority complex has rooted itself in his existence and sometimes can be seen in his words and behaviour of his daily life.

Imam Ali (pbuh) says: "often your utterances and expressions of your face leak out the secrets of your hidden thoughts." 
It is clear that unconscious mind has role in every aspect of a person's personal and social life and willingly or unwillingly, it can be seen in his action.

As per the saying of Imam Ali (pbuh), Freud believes, some of the incidents and desires disturb a person emotionally, and unintentionally become out casted, and in those situation they may affect our lives too. Unconscious forces are present even in minor behaviours. Movement of a part of a body, scrawling on a paper, joking and smiling, all these can be the unconscious meaning.

For example, instead of saying "I am happy that you are fine" we say "I am happy that you are not fine". (Rita L. Atkinson and...)

Thus, a man should be very careful about his behaviour and speech, because a daily behaviour of a person shows his inner personality, which sometimes can be seen with the expression of the faces and slip of tongues. Imam Ali (pbuh) in Nahjul Balagha wisdom 148 says: "Speak to get known, indeed man is hidden under his tongue".

Maulana Jalal-Uddin Balkhi has composed a beautiful couplet to support the saying of Imam Ali (pbuh):

1. Each phrase itself is a sign of a position

2. Position, like hand and phrase is like tool

3. Man is hidden under his tongue

4. This tongue is like a veil on the shrine of soul

5. Since God called the face as the representative

6. Eyes of a mystic is gazed on the face

Given the above content we can understand, that slip of tongue gives us a glimpse from deep inside of a man, which sometimes unconsciously and unwillingly appears in ones speech and action.

Imam Ali (pbuh) has mentioned these facts centuries ago in his wisdoms and today after few centuries have psychologists have reached to this fact.

Sigmund Freud, a contemporary psychologist, also believes that mind of a human is like iceberg which is floating in the middle of an ocean; if we divide this iceberg in three parts, the conscious mind will be considered as peak of iceberg and sub-conscious mind will be considered as the middle section, and the biggest section of that iceberg which is under that deep ocean, and is hidden from our sight is unconscious mind, and sometimes the content of unconscious mind exchanges place with the conscious mind and can be seen in our behaviour and action. (Ali Akbar Seyasi, 1991).

Regarding the slip of tongue Sa'di has composed a beautiful couplet:

1. Until man doesn't speak

2. His strengths and weaknesses are hidden

3. Don't think each grove is a sapling

4. It can be a leopard is sleeping there. (Gulestan Saadi, 1984). 


\section{CONCLUSIONS}

Even though view point of Imam Ali (pbuh) regarding pedagogy and psychological issues are fourteen centuries old, but have been described as precise and deep. However, after centuries of research and study scientists and researchers have decoded or are decoding many conceptual and semantic perspectives.

This research shows wherever Imam Ali (pbuh) has spoken about autognosis, he has considered God cognition as its result, while psychologists have just used the word of "reaching perfection". 


\section{References}

A'arafi; Ali Reza. (1997). An Introduction to Islamic education (2). Studying the university books.

Abbas Nejad; Mohsen. (2005). Quran-Psychology and Educational Sciences, Tehran, library and information center expert Quran and Science Day.

Alipour; Mohammad. Creative Efectson Memory, MasterThesis, Tehran. Institute of Psychology.

AlanO. Ross. (1992). Psychology of Personality. Translator: Seyavash Jamal Far, Tehran, BeastPress.

Allama Majlisi; Mohammad Baqer, Bihar al-Anwar, Tehran, Esla my book store.

Amodi; Abdul Wahed, Ghorarolhekam and Dorarol kalem, Qom, Office of Islamic Culture Publication

Aryanpour. (1970). Freudism, Tehran, PocketBookCompany

B. R. Hergenhan and Meteyo. H. Alson. Theories of Personality and schoolpsychology. Translator: Ali Akbar seyf, Tehran, Doran Publication.

Dadsetan; Parirokh, Adler and Adlernegary. Journal of Psychology. First Year, Issue 40.

David Burns. (2001). Well we had abad, translation: Mahdi Gharachedaghi,Tehran.

Davoodi; Hoseyn and.... Persian literature 2 (theoretical, vocational). Tehran, Iran Company Anthology textbooks.

Hes Fyst and Gregory J.Fyst. (2005). Theories of Personality. translation: Yahya Seyed Mohammadi, Tehran.

John and Bekuo. (2004). Psychology of Santrak, Translator: MehrdadFiroozbakht, Tehran.

Karimi, Yusuf. (1994). SocialPsychology, Tehran, PressNoor.

Koleini Mohammad Yaqub. (2002). Principlessufficient, Tehran, publications, examples, Fifth Edition.

Mostafa; Rahimi. (2006). Biography of a hundred and ten poets. writers-scientists. Tehran, Jahanara.

The Holy Quran.

Pakseresht; Mohammad Jafar and Hussaini, Ali Akbar.Introduction to Education; Philosophy of Education. Tehran, studying the humanities and the university books

Payandeh; Abilqasem, Nahjul Fasaha, Tehran. 
Pour. Majed, sense of inferiority, Journal of Transplantation. Tehran, Central Organization of Parents and Teachers, No. 129.

Ricky. L. Krystany Terzas. George and counseling theories and applications. Translated by Reza Fallah and Mohsen Hajilo, Tehran.

Rita. L. Atkinson. (2006). Background Psychology Hilgard, translation: Hasan Rafiee,Tehran, Volume 1.

Rita. L. Atkinson. (2006). Hilgard field of psychology, translators: Mohammad Naqi Baraheni, Tehran, Volume 1.

Rustam Ali Musa Oghliyof, Golestan, Tehran. Schultz and Sydney Ellen Schultz. Theories of Personality. Translator: Yahya Seyed Mohammadi, Tehran, publishing editing.

Seyasi; Ali Akbar. (1991). Theory of personality and school psychology. Tehran.

Shakerin, Hamid Reza. (2006). Questions and Answers. 5 printing, publishing Education, Qom.

Shamlou; Saied. (2003). School psychology and theories of personality.Tehran.

Sharafi; Mohammad Reza, Life Skills Sire Razavi, Hossein under Dehnaviand...Mashhad Qods Razavi.

Syed Razi, Nahjul balagha Amir (as), Translator: Mohammad Dashti, Qom, Amir Research institution.

Sydney Ellen Schultz. Theories of Personality.Translator: Yahya Seyed Mohammadi, Tehran, publishing editing.

Vatvaat; Rushd Uddin. (1986). Best of the Taleb, Qom, Salmanthe Persian. Schultz and. 31 